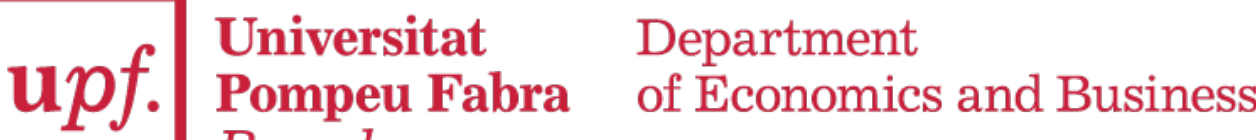 Barcelona
}

Economics Working Paper Series

Working Paper No. 1629

\section{Mother's care: reversing early childhood health shocks through parental investments}

Cristina Bellés-Obrero, Antonio Cabrales, Sergi Jiménez-Martín and Judit Vall-Castello

January 2019 


\title{
Mothers' care: reversing early childhood health shocks through parental investments *
}

\author{
Cristina Bellés-Obrero ${ }^{1,7}$, Antonio Cabrales ${ }^{2}$, Sergi Jiménez-Martín ${ }^{3,4,5}$ and Judit Vall-Castello ${ }^{6,7}$ \\ ${ }^{1}$ Department of Economics, University of Mannheim, \\ ${ }^{2}$ Department of Economics, University College of London, \\ ${ }^{3}$ Department of Economics, Universitat Pompeu Fabra, \\ ${ }^{4}$ Barcelona GSE, \\ ${ }^{5}$ FEDEA, \\ ${ }^{6}$ Department of Economics \& Institut D'economia De Barcelona (Ieb), Universitat de Barcelona \\ ${ }^{7}$ Center for research in Economics and Health, Universitat Pompeu Fabra
}

\begin{abstract}
We explore the effects of a child labor regulation that changed the legal working age from 14 to 16 over the health of their offspring. We show that the reform was detrimental for the health of the son's of affected parents at delivery. Yet, in the medium run, the effects of the reform are insignificant for both male and female children. The sons of treated mothers are perceived as still having worse health at older ages, even if their objective health status has recovered. These boys are also more likely to have private health insurance, which suggests more concerned mothers.
\end{abstract}

JEL-CODES: J81, I25, I12, J13

KEYWORDS: minimum working age, education, child health, gender

\footnotetext{
${ }^{*}$ We gratefully acknowledge the support from projects ECO2014-52238-R and ECO2017-82350-R, and the Collaborative Research Center TR 224 - EPoS. R. Sergi Jimenez acknowledges financial support from the Spanish Ministry of Economy and Competitiveness, through the Severo Ochoa Programme for Centres of Excellence in R\&D (SEV-2015-0563)The usual disclaimer applies.
} 


\section{Introduction}

Health shocks at birth are important in and of themselves. But they also contribute to explain outcomes later in life, such as education and productivity. A growing body of research shows that early life conditions can have lasting effects. Examples of events that produce such shocks are pandemics, famines, armed conflicts, radioactive emissions, and weather shocks (Almond, 2006; Leon, 2012; Akresh et al., 2012; Black et al., 2013). But there is much less research about the factors which compensate those early life shocks. In this paper we find one such factor. We study the causal effect of a child labor regulation on the short and long-term health of the affected individuals' descendants. In that context we show that a negative health shock for newborns disappears in the medium run for children of educated parents.

We show that a child labor reform in Spain, that increased the education of both women and men, is detrimental for their male children's health at delivery. At birth, male babies from more educated mothers have worse perinatal health outcomes, such as lower birth weight or low maturity. Those outcomes are statistically independent of maternal education for female babies. The effects are quantitatively significant. We estimated that the reform caused 618 more births at less than 37 weeks of gestation, 837 more first multiple births, and 768 extra births with low birth weight (as mentioned before these effects are all for boys).

Our short-term effects over infant health are of similar magnitude to the effects of other events that have been shown to have an impact on birth outcomes. Women affected by the reform had a 0.26 percentage-points higher probability of having a boy with low birth weight, and had boys that weighted 7 grams less on average. These estimates are equivalent to changes in birth weight and the incidence over low birth weight induced by other shocks in early life conditions, such as nutritional programs that targeted pregnant women (Almond et al., 2011; Hoynes et al., 2011), or exposure to stress during pregnancy (Camacho, 2008; Mansour and Rees, 2012; Quintana-Domeque and Ródenas-Serrano, 2017).

Furthermore, there is an extensive medical literature that has established a strong correlation between low birth weight and adverse health and developmental outcomes for children (Hack et al., 1995; Escobar et al., 1991; Kitchen et al., 1980; Overpeck et al., 1989; McCormick et al., 1993). In addition, some papers also show the causality behind this correlation; Johnson and Schoeni (2011a), Johnson and Schoeni (2011b), and Case et al. (2005), using within-siblings fixed effects estimates, show that the probability of been born with low birth weight has a significant effect over children's and adults' subjective and objective health.

Thus, both the size of the effects that we find on birth outcomes as well as the established links between health at birth and long-term health, would suggest that the deterioration of infant health at birth would persist in the medium and long term and would affect children's health unless there is a compensation mechanism. Yet, in the medium run, we find that the effects of the reform on objective health outcomes are insignificant for both males and females. Thus for educated parents it is possible to reverse negative shocks at birth. Our data suggest that the long

term reversal is achieved through maternal vigilance. The male children of treated mothers with higher education are perceived as having worse health even at older ages. Their objective health status is, however, indistinguishable 
from that of other boys. This suggests more concerned mothers. These boys are also more likely to have private health insurance. This latter trait is significant. In Spain private health insurance is purchased in addition to the universal public health coverage. This double coverage allows beneficiaries to avoid the system gatekeeper and, hence, to have quicker access to specialists and additional tests and checkups. We also report that these effects are only coming from treated mothers whereas the impacts are not significant for treated fathers.

We take advantage of a legislative change to identify the causal impacts in our study. The Workers' Statute (Law 8/1980) enacted in 1980 raised the minimum legal working age in Spain from 14 to 16 years old, while keeping the compulsory schooling age at 14 . This change affected only individuals born after 1966, who were 14 at the time the law was passed. Thus, the groups to be compared are students becoming 14 just after the reform to those who did it just before the reform. This is still unsatisfactory as individuals from different cohorts might be different. We have reasons to believe that this is the case for Spain in the 1980, a time of large social and political change. So we also exploit the fact that not all individuals from the same cohort were affected by the reform in the same way.

At the time of the enactment of this law, primary education finished in the year students turned 14 years old. Before the reform, students born early in the year reached the minimum legal working age in their last year of primary education. This created an incentive to leave school before completing primary education. On the other hand, students born during the last months of the year were not old enough (not yet 14 years old) to legally work before finishing school. Hence, they had no reasons to abandon early primary education. Thus, students born early in 1966 had incentives to complete primary education, compared to students born early in 1965. At the same time students born later in the years 1965 and 1966 did not experience a similar change. This lead to the observed change intra-cohort education difference and offspring health outcomes. We established those changes in a previous paper, Bellés Obrero et al. (2015).

In Bellés Obrero et al. (2015), we document three channels contributing to the short-term effect of the child labor reform over infant health. One of them, an improvement in the labor market conditions of more educated women, is particularly important. It increased (for that generation) the likelihood of engaging in unhealthy behaviors such as smoking.

Previous literature has studied differential effects of maternal environment over male and female babies. Our main contribution over that literature is to study long term effects of perinatal shocks. That literature has examined, for example, the effect of stress over the population in the reduction of secondary sex ratios: earthquakes (Fukuda et al. (1998)), environmental disasters (Lyster (1974)), war (Graffelman and Hoekstra (2000); Zorn et al. (2002)), mass layoffs (Catalano et al. (2012)) or the collapse of the economy (Catalano (2003)). This literature argues that hormones induced by stress increase the probability of spontaneous abortions at an early stage of pregnancy, and these hormones have a larger effect on male than on female fetuses (Hobel et al. (1999), Byrne et al. (1987)). In the specific case of Spain, Alonso et al. (2006) found a higher male neonatal mortality during 1975 and 1998. Moreover, previous medical literature has established that male fetus are more affected than female by maternal smoking (Zaren et al. (2000)), air pollution (Ghosh et al. (2007)) or high caffeine consumption during the third trimester of pregnancy (Vik et al. (2003)). Finally, male newborns have also a higher probability of being preterm 
(Zeitlin et al. (2002)).

The remainder of the paper is organized as follows. Section 2 presents the institutional context as well as the identification strategy. In Section 3, we analyze the effect of the reform children's health. Finally, Section 4 concludes with a discussion of the main results and their policy implications.

\section{Institutional Context and Identification Strategy}

\subsection{The Child Labor Reform in Spain}

In 1980, just a few years after the end of the dictatorial regime in Spain, a new child labor regulation (Law 8/1980) was enacted which changed the minimum legal age to work from 14 to 16 years old. Before the reform, Spain was characterized by having a considerable percentage of their population participating in the labor market at an early age. In the late 1970s, 40 (30) percent of 15-years-old and 15 (10) percent of 14 years-old boys (girls) were participating in the formal labor market (Labor Force Survey). Moreover, 30 (20) and 10 (8) percent of boys (girls) were formally working at the age of 15 and 14, respectively. These percentages are important if we take into account that a substantial part of the employment of children under the age of 16 was probably in the informal market and, thus, not captured in the Spanish Labor Force Survey. These employment percentages were slightly lower during in the first quarter of 1980, when the law was enacted. In 1980, 20 (10) and 5 (5) percent of the 14 and 15 years-old boys (girls) were working.

Yet, the Spanish educational system was regulated at that time by the General Law of Education of 1970 (Ley General de Educación) that was in force until 1990. This law established compulsory education until the age of 14, which remained constant before and after the child labor reform. Primary education (Educación General Básica) lasted 8 years. In Spain all children from the same cohort start school the calendar year they turn 6 years-old. Consequently, some children were 5 years old when they started primary school, while others started with 6 years old and are thus a bit older (in months). At the same time, some children finished primary education at 13, while other finished it at 14 years old.

The child labor reform introduced an exogenous variation in the incentive to stay in the educational system depending on the year and month of birth of the individual. First, individuals born after 1966, who were 14 at the time the reform was passed, could not start working until they turned 16 years old, while individuals born before 1966 could start working at the age of 14 . Additionally, individuals from the same cohort were affected differently by the reform depending on whether they were born at the beginning or the end of the year. Before the reform, students born during the first months of the year turned 14 before finishing their last year of primary education, and had incentives to leave the educational system without completing it. Instead, students born during the last months of the year were not old enough (had not turned 14 years old) to start legally working before finishing primary education. After the reform, this difference in incentives disappears. The reform increased the legal working age 
to 16 years old, but the compulsory schooling age remained at 14 . Thus, after the reform, all individuals in the same cohort had similar incentives to complete the last year of primary education as they were not able to work until turning 16.

The following chart illustrates the timing of the reform by showing two individuals in the same 1963 cohort (prereform), during their last year of primary schooling:

1. An individual that was born on February of 1963:

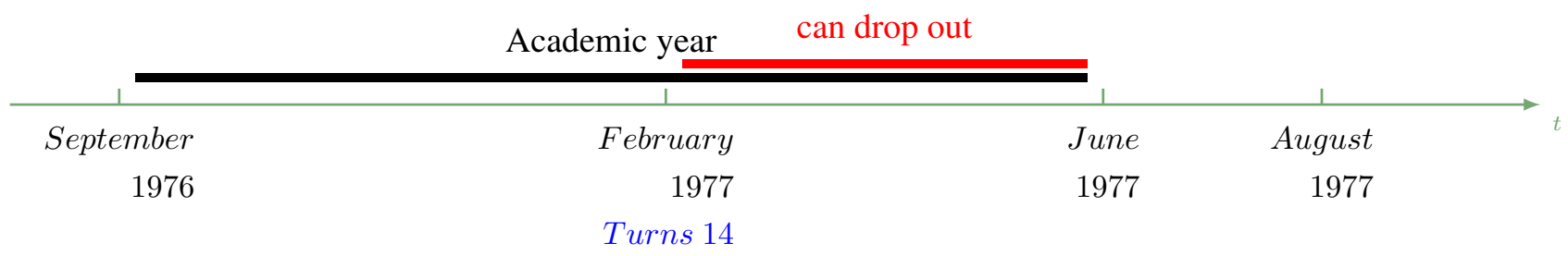

2. For an individual that was born on August of 1963:

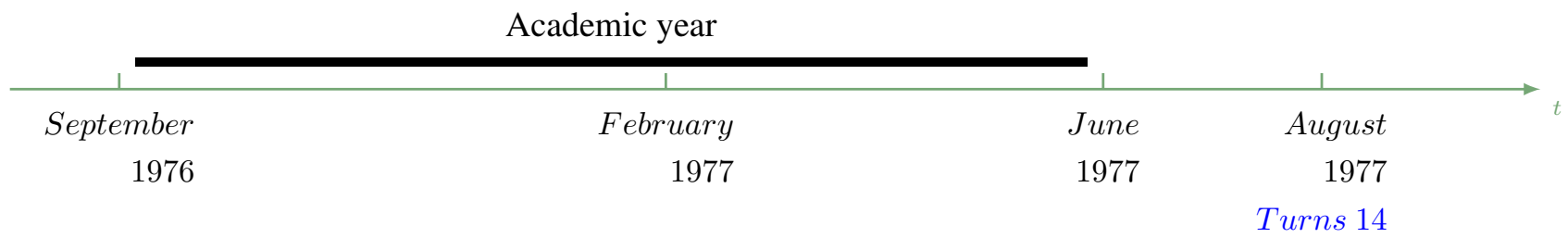

The individual that was born in February of 1963 would have turned 14 years old in February of 1977 and could have dropped out of school before completing the last year of primary education, which finished in June of 1977. While the individual born on August of 1963 was still 13 in June of 1977, when the last year of primary school finished.

\subsection{Estimation Strategy}

We perform a within-cohort difference-in-difference strategy to identify the effect of the reform on the (short-term and medium-term) health of the affected individuals' offspring. In our identification, we are comparing children whose mother belong to the same cohort and only differ in the month of birth. Thus, we compare children whose mothers were born at the beginning of the year with children whose mothers were born at the end of the same year, for cohorts of mothers who turn 14 just before the reform (1965 and earlier cohorts) and those who turned 14 just 
after the reform (1966 -from April onwards- and later cohorts).

First, we consider the following econometric model for several infant health outcomes at the moment of delivery of child $j$ observed in year $t$, who is related to mother $i$ from cohort $c$ :

$$
\begin{gathered}
\text { Outcome }_{j t}^{i c}=\alpha+\beta_{1} \text { Treated }_{i}+\beta_{2} \text { Treated }_{i} * \text { Post Re form }_{i} \\
+B Y_{c}+C Y_{t}+R_{s}+\epsilon_{j t}^{i c}
\end{gathered}
$$

where Treated $_{i}$ is a dummy variable that equals one if the mother $i$ was born between January and May and zero if she was born between July and December (we do not consider those individuals born in June, which coincides with the end of the academic year in Spain). Post Re form $i$ is also a dummy variable that takes a value of one if the mother $i$ turned 14 after the reform and zero otherwise. We define the pre-reform cohorts of mothers as those born between 1961 and 1965, and post-reform cohorts as those born between 1967 and 1971. We also include birth year dummies of the mothers $\left(B Y_{c}\right)$, calendar year fixed effects $\left(C Y_{t}\right)$, and region fixed effects $\left(R_{s}, 17\right.$ regions). Finally, the model includes an error term, $\epsilon_{j t}^{i c}$.

The model is estimated by Least Squares and the estimated standard errors are clustered at the cohort level. As there are only 9 clusters, we also calculate and report the p-value of the wild bootstrap with 1000 replications. The effect of the reform can be identified by the coefficient of the interaction between the post-reform and the treatment dummy variable, $\beta_{2}$.

When examining the medium-term effects of the reform over the affected individuals' children, we use the same econometric model as before but, in addition, we also control for the children's age at the moment of the interview adding both a linear and a quadratic terms. We also include a dummy indicating whether the mother is the one responding to the children's interview.

Finally, we analyze the effect of the reform on the probability that the mother with children has taken out private insurance. In this case the econometric model will be set at the mother's level $i$ from cohort $c$.

$$
\begin{gathered}
\text { Outcome }_{i c t}=\alpha+\beta_{1} \text { Treated }_{i}+\beta_{2} \text { Treated }_{i} * \text { Post Reform }_{i} \\
+B Y_{c}+C Y_{t}+R_{s}+\epsilon_{i t}
\end{gathered}
$$

\subsection{Data and Descriptive Statistics}

In order to examine the effect of the child labor reform on the affected women's offspring infant health outcomes we use administrative data from the birth certificate records. Thus, we have the universe of children born in Spain between 1975 and 2014. This data is available from the Spanish National Statistics Institute and contains information about the newborn that is self-reported by their parents or relatives that are obligated by law to declare the 
childbirth. We restrict our sample to first births of Spanish women born between 1961 and 1971 that had 14 to 43 years old at the moment of delivery. Birth weight is only available from the year 1980 onwards, so we restrict our birth weight sample to first birth of Spanish women from cohorts 1962-1971 that had 18 to 43 years old at the moment of delivery. We also drop births of women born in 1966, who were 14 the year the reform took place, and those of women born in June. Thus, our final sample has a total of 2,493,107 first births. We report the descriptive statistics of the main infant health variables used in Table A1, separately for first birth (female and male) of women born at the beginning of the year (Treated) and at the end of the year (Not Treated). We can observe that around 90-91\% of children are born with 37 or more weeks of gestation, and boys have a higher probability of being premature, as suggested by the medical literature. Also, around 3\% of the reported first births in the sample are multiple births and $99.8 \%$ of the observed first births survive the first 24 hours after delivery. Finally, boys are born in average with 3,250 grams and $6.5 \%$ of them are born with low birth weight, while girls weight a around 150 grams less at birth and have almost 1.5 percentage points higher probability of being born with low birth weight compared with the boys.

To examine the medium-term effects on the health of the women's offspring we use two different databases. We use three waves (2003, 2006 and 2012) of the Spanish National Health Survey (SNHS). This is a nationwide crosssectional survey that collects health related information as well as the socio-economic status and habits of adults and children (up to 15 years old). We again restrict our sample to mothers of children aged 2 to 15 years old at the moment of the interview that were born between 1961 and 1971 (dropping those mothers born in 1966 and born in June and July ${ }^{1}$ ). We focus on the health and habits information of children aged 2 to 15 , which is self-reported by one of their parents. The descriptive statistics of the main variables can be observed in Table A2. We use two main measures of children's health: the probability of having self-reported (subjective) good health, the probability that the child has good objective health (defined as not having diabetes, asthma, chronic allergies, or mental disorders). $80 \%$ of the boys in our sample do not suffer from diabetes, asthma, chronic allergies or mental disorders, while this percentage is a bit higher for girls $(84 \%)$. On the other hand, a higher percentage mothers self-report that their children have a good subjective health (90\%), independently of the gender of the child. We also report some habits of the children, such the probability of eating fruits and vegetables, proteins (meat, fish or eggs), cereals (bread of pasta) everyday, or the probability of having bad habits like eating cold meat or having nothing for breakfast everyday.

We also use the 2000 wave of the European Community Household Panel (ECHP, see Peracchi (2002) for a description) database to study the effect of the reform on the probability of having a private (complementary to the public) insurance. This is a cross-sectional database that contains detailed information on income, financial situation, working life, social relations and health of the household's members of those individuals that are being interviewed. The ECHP has 8 waves, from 1994 to 2001 for Belgium, Denmark, Germany, Ireland, Greece, Spain, France, Italy, Luxembourg, the Netherlands, Austria, Portugal, Sweden and the United Kingdom. However, for the case of Spain, only the (extended) 2000 wave of the ECHP has information regarding health insurance. Again,

\footnotetext{
${ }^{1}$ We additionally had to drop mothers born in July because of the last wave (2012) of the SNHS reports the month of birth in brackets. However, all the results obtained using the Birth Statistics are robust to the exclusion of mothers born in July
} 
we restrict our sample to mothers of children aged 2 to 15 years old at the moment of the interview that were born between 1961 and 1971 (dropping those mothers born in 1966 and born in June and July). We can observe in Table A3 that around $10-15 \%$ of the households with children have private insurance. This percentage is higher, thought, in households where all children are female or when there is only one child that is a girl.

\section{Effect of the reform on infant health}

\subsection{Objective health outcomes (at birth and medium-term)}

The first fact we want to highlight is the striking differential impact of the child labor reform on infant health at delivery, which is negative for boys only. To examine this impact, we use birth register data and five measures of newborn health: the fraction of babies that are born after more than 37 gestational weeks, ${ }^{2}$ the fraction that are multiple births, the fraction that die within the first 24 hours of life, birth weight (in grams) and the fraction born weighing less than 2,500 grams. ${ }^{3}$ Birth weight and survival data are only available from 1980 to $2012 .{ }^{4}$ Thus, when analyzing these outcomes, we drop the 1961 cohort from the pre-reform group and restrict the sample to all births that took place when the mother was between the ages of 18 and $41 .^{5}$ Note that this analysis only examines the infant health of the woman's first child. ${ }^{6}$ We cannot restrict our sample to single first births as the probability of having multiple birth is affected by the reform. ${ }^{7}$

Table 1 reports the effects of the reform on infant health outcomes for all the first children separately by the gender of the child. First, we find that the reform had an effect over the probability of having a child born with less than 37 gestational weeks, that is very similar for boys and girls. Thus, after the reform, the first child of a woman (boy or girl) born at the beginning of the year has a 0.234 or 0.214 percentage-point higher probability of being premature. On the other hand, we find that the reform had no effect on the probability of having a late fetus death or the probability of the first children dying during the first 24 hours, again independently on the gender of the child.

The remaining effects of the reform over the health of children is different depending on the gender of the first child. The reform caused women born at the beginning of the year to have boys that weighed 7 grams less, on average, compared to boys of women born at the end of the year. We also estimate, for example, that after the reform, women born at the beginning of the year have a 0.26 percentage-point higher probability of having a first

\footnotetext{
${ }^{2}$ We select 37 gestational weeks as a threshold because babies born earlier than that are considered premature from a medical perspective.

${ }^{3}$ Babies born with less than 2,500 grams are considered to be low birth weight by medical standards.

${ }^{4}$ Note that we also have 11 percent of registered first births where the birth-weight is missing.

${ }^{5}$ Note that as we showed in Bellés Obrero et al. (2015) the reform did not have an effect on the probability of women having the first child before the age of 18 .

${ }^{6} \mathrm{We}$ include this restriction because a poor health outcome for the first birth can influence the decision to have a second child, as pointed out by Wolpin (1993)

${ }^{7}$ However, the main results are consistent if we exclude multiple births from our sample. However the sample excluding multiple births will have sample selection problems.
} 
boy with a low birth weight (less 2,500 grams). We do not see the same pattern over weight for first children that are girls.

The impact of the reform over boy's average birth weight and the probability of being born with less than 2,500 grams is stronger to changes in birth weight brought on by several US federal nutrition programs that targeted pregnant women (Almond et al., 2011; Hoynes et al., 2011) ${ }^{8}$. Moreover, the magnitude of our estimated effects is also similar to those found in the literature for pregnancy stress exposure. Camacho (2008) shows that first-trimester exposure to landmine explosions in Colombia is associated with a 9 grams reduction in birth weight. Mansour and Rees (2012) find that intrauterine exposure to an additional fatality is associated with a decrease in birth weight of 2.1 grams, and a 0.0019 percentage-point increase in the probability of having a child that weighted less than 2,500 grams at birth. Also, Quintana-Domeque and Ródenas-Serrano (2017) estimates an average birth weight decrease of 0.3 grams, or $0.15-0.19$ over 1,000 births more low-weight births per bomb casualty in the first trimester of pregnancy in Spain.

It has been well documented by the medical literature that being born with less than 2,500 grams is correlated to adverse health and developmental outcomes for children (Hack et al., 1995; Escobar et al., 1991; Kitchen et al., 1980; Overpeck et al., 1989; McCormick et al., 1993). In addition, some other papers examine the causality behind this correlation. Johnson and Schoeni (2011b) show, using within sibling FE that the probability of having been born with low birth weight has a significant effect over children's ( 0 to 12 years old) and adults' subjective health. Likewise, Case et al. (2005) find that low birth weight is associated with decrease in a subjective health index (ranging from 0 to 4 ) of $0.054,0.07$ or 0.09 points at the age of 23,33 and $42 .{ }^{9}$. Given these previous evidence, we expect the negative impact of the reform over the probability of being born with less than 2,500 grams to affect children's health in the medium-run if nothing is done to compensate it.

Finally, we also find that if the first child of the woman affected by the reform was a boy, there was a 0.29 percentage point higher probability that this first birth was a multiple birth. This might be a consequence of the postponement of the entrance into motherhood. Bellés Obrero et al. (2015) show that the reform decreased the probability of women having the first child between the ages of 18 and 21 and increased the incidence of first births after the age of 35, the age when women's fertility begins to drop. Many of these women might start receiving infertility treatment, which often results in multiple pregnancies. Also, at ages 35 ore more, the probability of having multiple birth increases, even without fertility treatments. ${ }^{10}$ Moreover, this detrimental effect over the

${ }^{8}$ Almond et al. (2011) estimate that having a US Food Stamp program in place in the third trimester of pregnancy increased the average birth weight of their children between 2 and 5 grams. Similarly, Hoynes et al. (2011) show that the Supplemental Program for Women Infants and Children raised average birth weight by 2 grams, or by 7 among infants born to mothers with low education levels.

${ }^{9}$ Other papers find that low birth weight is also associated with long-run negative outcomes over labor market earnings, education and adults' objective health (see Black et al. (2005), Figlio et al. (2014), Cook and Fletcher (2015), Behrman and Rosenzweig (2004), or Johnson and Schoeni (2011a), for instance).

${ }^{10}$ In Bellés Obrero et al. (2015), we document three different channels contributing to the detrimental effect of the child labor reform on infant health at delivery: the postponement in age of delivery, the change in the maternal marital status, and a higher probability of having a high skill job of more educated women, which increases the 
short-term health of the offspring at the time of delivery is not present for the children of father's affected by the reform. We can observe in Tables A4 that the reform had a precisely estimated zero effect over the children's health at birth of those men affected by the reform.

In order to examine the medium-run effects of the reform over children's health, we use repeated cross-sectional data of three waves (2003, 2006 and 2011) of the Spanish National Health Survey. In this paper, we will focus only on the health (and habits, in the following section) information for children aged 0-15. As a objective health measure we use the probability of not having any of the following diseases: diabetes, asthma, chronic allergies, or mental disorders. The last two columns of Tables 1 report the medium-run effects of the reform on these children's health outcomes using the econometric model specified before, differentiating by the gender of the child. As one can easily see, the objective good health status seems to be affected in the opposite way. While girls' objective health is still not affected by the reform, boys from mothers' affected by the reform had a 4.8 higher probability of having a good objective health.

\subsection{Mechanism}

Previous literature has studied differential effects of maternal environment over male and female babies. Our main contribution over that literature is to study long term effects of perinatal shocks. The reform caused women born at the beginning of the year to have boys that weighed 7 grams less, on average, compared to boys of women born at the end of the year. We also estimate, for example, that after the reform, women born at the beginning of the year have a 0.26 percentage-point higher probability of having a first boy with a low birth weight. In the long-run, the objective good health status seems to be affected in the opposite way. While the girls' objective health is still not affected by the reform, boys from mothers' affected by the reform had a 4.8 higher probability of having a good objective health.

The reversal of the negative effects of the reform for boys between the moment of delivery and the teenage years is a very striking finding. In the present section we investigate two potential mechanisms for achieving this effect: habits and maternal vigilance. Parents can contribute to a better health by ensuring their offspring make lifestyle choices that are more conducive to good outcomes. They can also invest in other preventive measures, like taking the children more often to the doctor.

With respect to habits, the answer appears to be negative. Table 2 reports the effects of the reform on eating and sleeping habits using the the econometric model specified before, differentiating by the gender of the child. More educated mothers have a positive impact over some habits of the children, but they are not consistent by gender. Table 2 shows that girls' of mothers affected by the reform had a higher probability of eating protein everyday, and have less bad habits. But the boys' of those mothers have better sleeping habits. Moreover, this effects of the reform on habits are not reinforced when we consider those cases where both parents are affected by the reform (Table A5). Thus, it would be hard to explain the reversal of outcomes at delivery of boys simply using healthy

likelihood of engaging in unhealthy behaviors such as smoking. 
habits.

The results from Table 3 are more encouraging about maternal vigilance as an explanation. We use the self-reported probability of having good health as a proxy for subjective health measure. We observe that the boys' born from mothers affected by the reform have a 3.4 percentage points ( 0.12 standard deviations) lower probability of having subjective good health, while the reform had no significant impact on girls' subjective health. Clearly, this would be a trigger a larger preoccupation by mothers about their male offspring's health. This is further reinforced by our finding that boys' of treated mothers have 10.7 percentage points higher probability of having private insurance (in Spain, where public coverage is universal, this is something done by individuals wishing to have a premium quality care as well as quicker access to specialized care). The effect is even stronger (and more significant), reaching a rather large 18.5 percentage points higher for boys that are only children of treated mothers. We insist on maternal (as opposed to parental) vigilance, because these effects are coming primarily from children where the person responding to the survey, the informant, was the mother (compare columns 5 and 6 in panel B of Table 3 ).

The picture that emerges is one of mothers who had smaller, more fragile, boys, and who even at age 15 still worry more about them (even if, objectively, the health does not seem to differ). Thus, they put a lot of care (like expensive private insurance) to guarantee they have a positive health status. That, in turn, leads to a reversal of the negative effects from birth.

\section{Discussion}

There is a large literature showing that health shocks at birth lead to important negative outcomes later in life. Yet, the literature has been unable to establish if there are factors that can compensate those early life shocks. This is important from a policy perspective. Not much can be done to avoid some of these negative early life shocks (earthquakes or environmental disasters are difficult to avoid). Thus, it will be useful to know how to reverse shocks affecting health, education or productivity. We contribute to this literature by identifying a channels to compensate a negative shock during the childhood. We do that by studying the causal effect of a child labor regulation in Spain on the health of the affected individuals' descendants. We report increases in men and women education as a result of the child labor reform. These lead affected women to postpone motherhood until an age which has detrimental effects for their babies at birth. But these negative effects at birth are only significant for boys and, more importantly, they disappear in the medium run.

We next explore the channels that can explain this important reversal of early life negative conditions in the medium term. First, parents contribute to a better health if their offspring make lifestyle choices that lead to good outcomes. Second, they can also make an investment in other preventive measures, like taking the children more often to the doctor. In our data, more educated mothers have a positive impact over some habits of the children. But there is no consistent different across gender, so they do not explain the health recovery experienced by boys. Yet, we show that mothers report that those (already) healthy boys have lower (subjective) good health. And we show that boys' of treated mothers have a significantly higher probability of having private insurance. This is consistent with the 
idea that more educated mothers remain worried for the health of their boys. This is true even if they have been able to reverse the negative health outcomes at birth.

Summing up, more educated mothers had smaller and more premature boys. They remain worried about the health of their boys (as they assess their health status not to be good when their actual health is, indeed, good). Because of that, they put a lot of care (for example, by providing them with private insurance) to compensate the negative health effects at birth. That, in turn, lead to a reversal of the negative effects at birth during childhood. 


\section{References}

Akresh, R., S. Bhalotra, M. Leone, and U. O. Osili (2012). War and stature: growing up during the nigerian civil war. The American Economic Review 102(3), 273-277.

Almond, D. (2006). Is the 1918 influenza pandemic over? long-term effects of in utero influenza exposure in the post-1940 us population. Journal of political Economy 114(4), 672-712.

Almond, D., H. W. Hoynes, and D. W. Schanzenbach (2011). Inside the war on poverty: The impact of food stamps on birth outcomes. The Review of Economics and Statistics 93(2), 387-403.

Alonso, V., V. Fuster, and F. Luna (2006). Causes of neonatal mortality in spain (1975-98): influence of sex, rural-urban residence and age at death. Journal of Biosocial Science 38(04), 537-551.

Behrman, J. R. and M. R. Rosenzweig (2004). Returns to birthweight. Review of Economics and Statistics 86(2), $586-601$.

Bellés Obrero, C., S. Jimenez-Martin, and J. Vall Castello (2015). The unintended effects of increasing the legal working age on family behaviour.

Black, S. E., A. Bütikofer, P. J. Devereux, and K. G. Salvanes (2013). This is only a test? long-run impacts of prenatal exposure to radioactive fallout.

Black, S. E., P. J. Devereux, and K. Salvanes (2005). From the cradle to the labor market? the effect of birth weight on adult outcomes. Technical report, National Bureau of Economic Research.

Byrne, J., D. Warburton, J. M. Opitz, and J. F. Reynolds (1987). Male excess among anatomically normal fetuses in spontaneous abortions. American journal of medical genetics 26(3), 605-611.

Camacho, A. (2008). Stress and birth weight: evidence from terrorist attacks. The American Economic Review 98(2), 511-515.

Case, A., A. Fertig, and C. Paxson (2005). The lasting impact of childhood health and circumstance. Journal of health economics 24(2), 365-389.

Catalano, R., C. Margerison-Zilko, S. Goldman-Mellor, M. Pearl, E. Anderson, K. Saxton, T. Bruckner, M. Subbaraman, J. Goodman, M. Epstein, et al. (2012). Natural selection in utero induced by mass layoffs: the hcg evidence. Evolutionary applications 5(8), 796-805.

Catalano, R. A. (2003). Sex ratios in the two germanies: a test of the economic stress hypothesis. Human Reproduction 18(9), 1972-1975. 
Cook, C. J. and J. M. Fletcher (2015). Understanding heterogeneity in the effects of birth weight on adult cognition and wages. Journal of Health Economics 41, 107-116.

Escobar, G. J., B. Littenberg, and D. B. Petitti (1991). Outcome among surviving very low birthweight infants: a meta-analysis. Archives of disease in childhood 66(2), 204-211.

Figlio, D., J. Guryan, K. Karbownik, and J. Roth (2014). The effects of poor neonatal health on children's cognitive development. The American Economic Review 104(12), 3921-3955.

Fukuda, M., K. Fukuda, T. Shimizu, and H. Møller (1998). Decline in sex ratio at birth after kobe earthquake. Human reproduction 13(8), 2321-2322.

Ghosh, R., J. Rankin, T. Pless-Mulloli, and S. Glinianaia (2007). Does the effect of air pollution on pregnancy outcomes differ by gender? a systematic review. Environmental research 105(3), 400-408.

Graffelman, J. and R. F. Hoekstra (2000). A statistical analysis of the effect of warfare on the human secondary sex ratio. Human Biology, 433-445.

Hack, M., N. K. Klein, and H. G. Taylor (1995). Long-term developmental outcomes of low birth weight infants. The future of children, 176-196.

Hobel, C. J., C. Dunkel-Schetter, S. C. Roesch, L. C. Castro, and C. P. Arora (1999). Maternal plasma corticotropinreleasing hormone associated with stress at 20 weeks' gestation in pregnancies ending in preterm delivery. American journal of obstetrics and gynecology 180(1), S257-S263.

Hoynes, H., M. Page, and A. H. Stevens (2011). Can targeted transfers improve birth outcomes?: Evidence from the introduction of the wic program. Journal of Public Economics 95(7), 813-827.

Johnson, R. C. and R. F. Schoeni (2011a). Early-life origins of adult disease: national longitudinal populationbased study of the united states. American journal of public health 101(12), 2317-2324.

Johnson, R. C. and R. F. Schoeni (2011b). The influence of early-life events on human capital, health status, and labor market outcomes over the life course. The BE journal of economic analysis \& policy 11(3).

Kitchen, W., M. Ryan, A. Rickards, A. McDougall, F. Billson, E. Keir, and F. Naylor (1980). A longitudinal study of very low-birthweight infants. iv: An overview of performance at eight years of age. Developmental Medicine $\&$ Child Neurology 22(2), 172-188.

Leon, G. (2012). Civil conflict and human capital accumulation the long-term effects of political violence in perú. Journal of Human Resources 47(4), 991-1022.

Lyster, W. (1974). Altered sex ratio after the london smog of 1952 and the brisbane flood of 1965. BJOG: An International Journal of Obstetrics \& Gynaecology 81(8), 626-631. 
Mansour, H. and D. I. Rees (2012). Armed conflict and birth weight: Evidence from the al-aqsa intifada. Journal of Development Economics 99(1), 190-199.

McCormick, M. C., K. Workman-Daniels, J. Brooks-Gunn, and G. J. Peckham (1993). Hospitalization of very low birth weight children at shcool age. The Journal of pediatrics 122(3), 360-365.

Overpeck, M. D., A. J. Moss, H. J. Hoffman, and G. E. Hendershot (1989). A comparison of the childhood health status of normal birth weight and low birth weight infants. Public health reports 104(1), 58.

Peracchi, F. (2002). The european community household panel: a review. Empirical Economics 27(1), 63-90.

Quintana-Domeque, C. and P. Ródenas-Serrano (2017). The hidden costs of terrorism: The effects on health at birth. Journal of Health Economics 56, 47-60.

Vik, T., L. S. Bakketeig, K. U. Trygg, K. Lund-Larsen, and G. Jacobsen (2003). High caffeine consumption in the third trimester of pregnancy: gender-specific effects on fetal growth. Paediatric and perinatal epidemiology 17(4), 324-331.

Wolpin, K. I. (1993). Determinants and consequences of the mortality and health of infants and children. Handbook of Population and Family Economics 1, 483-557.

Zaren, B., G. Lindmark, and L. Bakketeig (2000). Maternal smoking affects fetal growth more in the male fetus. Paediatric and perinatal epidemiology 14(2), 118-126.

Zeitlin, J., M.-J. Saurel-Cubizolles, J. de Mouzon, L. Rivera, P.-Y. Ancel, B. Blondel, and M. Kaminski (2002). Fetal sex and preterm birth: are males at greater risk? Human Reproduction 17(10), 2762-2768.

Zorn, B., V. Šučur, J. Stare, and H. Meden-Vrtovec (2002). Decline in sex ratio at birth after 10-day war in slovenia brief communication. Human Reproduction 17(12), 3173-3177. 


\section{Tables and Figures}

Table 1: Effect of the reform on children's objective health outcomes at delivery and in the medium-term by gender

\begin{tabular}{|c|c|c|c|c|c|c|}
\hline & \multicolumn{6}{|c|}{ Girls } \\
\hline & \multicolumn{5}{|c|}{ At Delivery } & \multirow{2}{*}{$\begin{array}{c}\text { Medium term } \\
\begin{array}{c}\text { Good Objective Health } \\
\text { (6) }\end{array}\end{array}$} \\
\hline & $\begin{array}{l}\text { Maturity } \\
\text { (1) }\end{array}$ & $\begin{array}{l}\text { Multiple birth } \\
\text { (2) }\end{array}$ & $\begin{array}{c}\text { Survival } 24 \mathrm{~h} \\
\text { (3) }\end{array}$ & $\begin{array}{l}\text { Weight } \\
\text { (4) }\end{array}$ & $\begin{array}{c}\text { Weight less } 2,500 \\
\text { (5) }\end{array}$ & \\
\hline \multirow[t]{3}{*}{ Treated } & 0.055 & 0.032 & 0.026 & 0.156 & 0.019 & -0.010 \\
\hline & $(0.051)$ & $(0.048)$ & $(0.025)$ & (1.973) & $(0.086)$ & $(0.007)$ \\
\hline & {$[0.352]$} & [0.695] & {$[0.384]$} & {$[0.966]$} & [ 0.877] & [0.116] \\
\hline \multirow[t]{3}{*}{ Treated* Post Reform } & $-0.234 * *$ & 0.187 & -0.042 & -2.544 & 0.107 & -0.010 \\
\hline & $(0.077)$ & $(0.112)$ & $(0.026)$ & $(2.831)$ & $(0.126)$ & $(0.014)$ \\
\hline & {$[0.016]$} & {$[0.163]$} & {$[0.248]$} & {$[0.423]$} & {$[0.462]$} & {$[0.506]$} \\
\hline Observations & $1,205,425$ & $1,205,425$ & $1,051,330$ & 938,607 & 938,607 & 2,622 \\
\hline R-squared & 0.014 & 0.021 & 0.000 & 0.011 & 0.009 & 0.032 \\
\hline BirthYear FE & YES & YES & YES & YES & YES & YES \\
\hline CalendarYear FE & YES & YES & YES & YES & YES & YES \\
\hline Region FE & YES & YES & YES & YES & YES & YES \\
\hline Mean pre-reform & 90.61 & 2.580 & 99.79 & 3157 & 7.055 & 0.856 \\
\hline \multirow[t]{4}{*}{ Std. dev. pre-reform } & 29.17 & 15.85 & 4.581 & 486.9 & 25.61 & 0.352 \\
\hline & \multicolumn{6}{|c|}{ Boys } \\
\hline & \multicolumn{5}{|c|}{ At Delivery } & Medium term \\
\hline & $\begin{array}{l}\text { Maturity } \\
\text { (1) }\end{array}$ & $\begin{array}{l}\text { Multiple birth } \\
\text { (2) }\end{array}$ & $\begin{array}{c}\text { Survival } 24 \mathrm{~h} \\
\text { (3) }\end{array}$ & $\begin{array}{l}\text { Weight } \\
\text { (4) }\end{array}$ & $\begin{array}{c}\text { Weight less } 2,500 \\
(5)\end{array}$ & $\begin{array}{c}\text { Good Objective Health } \\
(6)\end{array}$ \\
\hline \multirow[t]{3}{*}{ Treated } & $0.068^{*}$ & 0.003 & -0.001 & 3.985 & -0.093 & -0.026 \\
\hline & $(0.031)$ & $(0.039)$ & $(0.008)$ & $(2.229)$ & $(0.086)$ & $(0.016)$ \\
\hline & [0.093] & [0.949] & {$[0.873]$} & {$[0.150]$} & [0.353] & {$[0.230]$} \\
\hline \multirow[t]{3}{*}{ Treated* Post Reform } & $-0.214 * *$ & $0.290 * * *$ & 0.001 & $-7.035 * *$ & $0.266^{*}$ & $0.050^{*}$ \\
\hline & $(0.083)$ & $(0.075)$ & $(0.011)$ & $(2.281)$ & $(0.115)$ & $(0.023)$ \\
\hline & {$[0.021]$} & {$[0.008]$} & {$[0.923]$} & {$[0.037]$} & {$[0.060]$} & {$[0.067]$} \\
\hline Observations & $1,287,682$ & $1,287,682$ & $1,121,994$ & 999,665 & 999,665 & 2,772 \\
\hline R-squared & 0.013 & 0.020 & 0.001 & 0.010 & 0.008 & 0.040 \\
\hline BirthYear FE & YES & YES & YES & YES & YES & YES \\
\hline CalendarYear FE & YES & YES & YES & YES & YES & YES \\
\hline Region FE & YES & YES & YES & YES & YES & YES \\
\hline Mean pre-reform & 90.25 & 2.460 & 99.75 & 3274 & 5.915 & 0.800 \\
\hline Std. dev. pre-reform & 29.66 & 15.49 & 4.983 & 517 & 23.59 & 0.400 \\
\hline
\end{tabular}

Notes: The dependent variables are some measures of infant health at the moment of delivery (the probability of (1) being born with more than 37 weeks of gestation, (2) being a multiple birth, (3) survive the first 24 hours after delivery, (4) birth weight, and (5) the probability of being born with less than 2,500 grams), and (6) children's medium-term good objective health. We consider that children have good objective health if he/she does not suffer from diabetes, asthma, mental disorders or chronic allergies. Regressions include cohort, calendar time and region dummies. Treated are individuals born from January to May, and control are those born from July to December. Robust standard errors clustered at cohort level in parentheses and the p-value of the wild bootstrap with 1000 replications in brackets. Source: (1-5) Birth registries (1975-2014), all women from cohorts 1961-1971. For birth-weight, only consider the birth registries from 1980-2014 and cohorts of women 1962-1971. (6) Spanish National Health Survey (2003, 2006, and 2011), all women with children from cohorts 1961-1971. Significance: $* * * \mathrm{p}<0.01, * * \mathrm{p}<0.05, * \mathrm{p}<0.1$. 
Table 2: Effect of the reform on mother's healthy habits

\begin{tabular}{|c|c|c|c|c|c|c|c|c|c|c|c|c|c|c|c|}
\hline & \multicolumn{3}{|c|}{ Fruit/Vegetables everyday } & \multicolumn{3}{|c|}{ Proteins everyday } & \multicolumn{3}{|c|}{ Cereals everyday } & \multicolumn{3}{|c|}{ Bad habits everyday } & \multicolumn{3}{|c|}{ Hours sleep } \\
\hline & $\begin{array}{l}\text { All } \\
\text { (1) }\end{array}$ & $\begin{array}{l}\text { Boys } \\
\text { (2) }\end{array}$ & $\begin{array}{l}\text { Girls } \\
\text { (3) }\end{array}$ & $\begin{array}{l}\text { All } \\
\text { (4) }\end{array}$ & $\begin{array}{l}\text { Boys } \\
(5)\end{array}$ & $\begin{array}{l}\text { Girls } \\
(6)\end{array}$ & $\begin{array}{l}\text { All } \\
\text { (7) }\end{array}$ & $\begin{array}{c}\text { Boys } \\
(8)\end{array}$ & $\begin{array}{l}\text { Girls } \\
(9)\end{array}$ & $\begin{array}{l}\text { All } \\
\text { (10) }\end{array}$ & $\begin{array}{l}\text { Boys } \\
\text { (11) }\end{array}$ & $\begin{array}{l}\text { Girls } \\
(12)\end{array}$ & $\begin{array}{l}\text { All } \\
\text { (13) }\end{array}$ & $\begin{array}{c}\text { Boys } \\
\text { (14) }\end{array}$ & $\begin{array}{c}\text { Girls } \\
(15)\end{array}$ \\
\hline \multirow[t]{3}{*}{ Treated Mother } & -0.006 & -0.004 & -0.011 & -0.035 & -0.013 & $-0.051^{*}$ & -0.010 & -0.010 & -0.006 & 0.003 & -0.000 & 0.006 & -0.042 & 0.022 & -0.100 \\
\hline & $(0.010)$ & $(0.012)$ & $(0.022)$ & $(0.018)$ & $(0.036)$ & $(0.016)$ & $(0.013)$ & $(0.011)$ & $(0.024)$ & $(0.002)$ & $(0.002)$ & $(0.005)$ & $(0.046)$ & $(0.044)$ & $(0.043)$ \\
\hline & {$[0.586]$} & {$[0.651]$} & {$[0.706]$} & {$[0.237]$} & {$[0.673]$} & {$[0.098]$} & {$[0.510]$} & {$[0.376]$} & {$[0.808]$} & {$[0.318]$} & {$[0.923]$} & {$[0.357]$} & {$[0.434]$} & [0.668] & [0.176] \\
\hline \multirow[t]{2}{*}{ Treated* Post Reform Mother } & 0.019 & 0.023 & 0.018 & $0.050^{*}$ & 0.036 & $0.059 * *$ & $0.034 *$ & 0.030 & 0.035 & -0.006 & 0.005 & $-0.017 * *$ & 0.071 & $0.131 * *$ & 0.002 \\
\hline & {$[0.340]$} & [0.307] & {$[0.666]$} & {$[0.055]$} & {$[0.468]$} & {$[0.037]$} & [0.077] & [0.121] & {$[0.256]$} & {$[0.127]$} & [0.143] & {$[0.026]$} & [0.417] & {$[0.050]$} & [0.991] \\
\hline Observations & 5,375 & 2,764 & 2,611 & 5,371 & 2,760 & 2,611 & 5,371 & 2,762 & 2,609 & 5,395 & 2,776 & 2,619 & 5,397 & 2,774 & 2,623 \\
\hline R-squared & 0.037 & 0.045 & 0.038 & 0.133 & 0.127 & 0.155 & 0.041 & 0.042 & 0.052 & 0.014 & 0.013 & 0.024 & 0.223 & 0.221 & 0.234 \\
\hline Calendar FE & YES & YES & YES & YES & YES & YES & YES & YES & YES & YES & YES & YES & YES & YES & YES \\
\hline Region FE & YES & YES & YES & YES & YES & YES & YES & YES & YES & YES & YES & YES & YES & YES & YES \\
\hline Cohort mother FE & YES & YES & YES & YES & YES & YES & YES & YES & YES & YES & YES & YES & YES & YES & YES \\
\hline Age controls & YES & YES & YES & YES & YES & YES & YES & YES & YES & YES & YES & YES & YES & YES & YES \\
\hline Mean pre-reform & 0.702 & 0.693 & 0.712 & 0.213 & 0.218 & 0.208 & 0.924 & 0.926 & 0.922 & 0.00839 & 0.00709 & 0.00972 & 9.233 & 9.216 & 9.249 \\
\hline
\end{tabular}

Notes: The dependent variables are the probability that a child, boy or girl $(1,2,3)$ eats fruits and vegetables, $(4,5,6)$ eats proteins (meat, fish or eggs), $(7,8,9)$ eats cereals (bread or pasta), $(10,11,12)$ has bad habits (eats cold meat or has nothing for breakfast) everyday, and $(13,14,15)$ children's hours of sleep a day. Regressions include cohort of the mother, calendar time, and region dummies. We also include children's age controls. Treated are fathers born from January to May, and control are those born from August to December. Robust standard errors clustered at the mothers's cohort level in parentheses and the p-value of the wild bootstrap with 1000 replications in brackets. Source: Spanish National Health Survey (2003, 2006, and 2011), all women with children from cohorts 1961-1971. Significance: *** $\mathrm{p}<0.01, * * \mathrm{p}<0.05, * \mathrm{p}<0.1$. 
Table 3: Effect of the reform on maternal vigilance

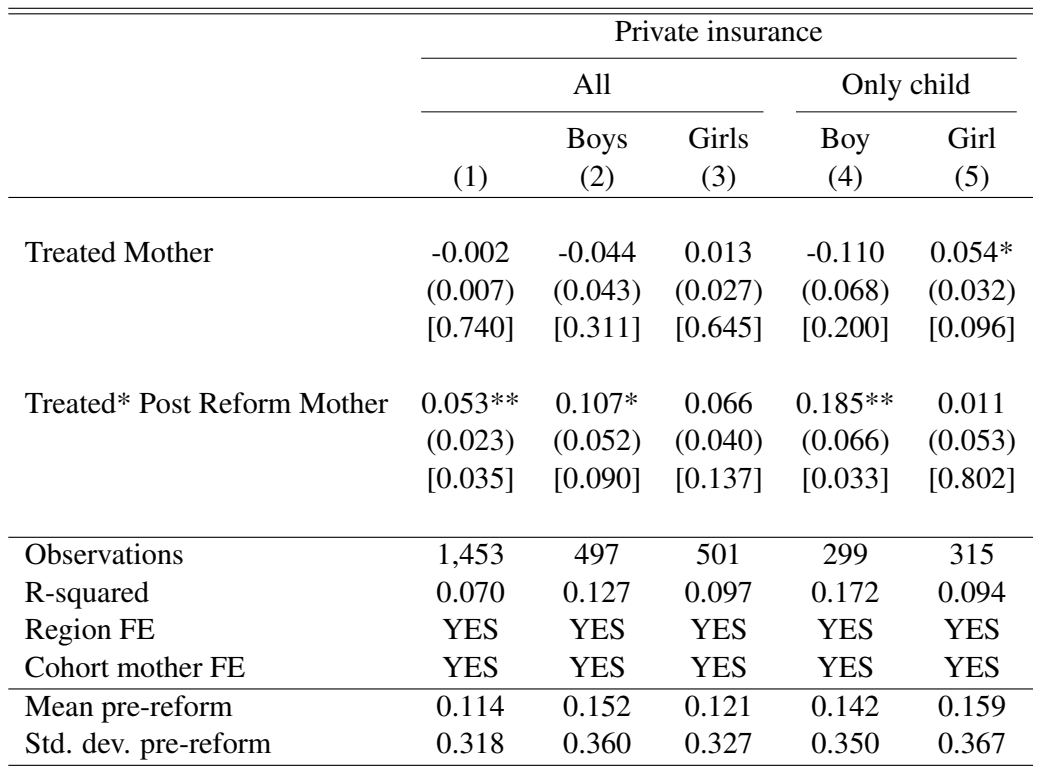

\begin{tabular}{|c|c|c|c|c|c|c|c|c|c|}
\hline & \multicolumn{9}{|c|}{ Subjective Good Health } \\
\hline & \multicolumn{3}{|c|}{ All } & \multicolumn{3}{|c|}{ Boys } & \multicolumn{3}{|c|}{ Girls } \\
\hline & $\begin{array}{l}\text { All } \\
(1)\end{array}$ & $\begin{array}{c}\text { Mother Inf } \\
\text { (2) }\end{array}$ & $\begin{array}{l}\text { Other Inf } \\
\text { (3) }\end{array}$ & $\begin{array}{l}\text { All } \\
(4)\end{array}$ & $\begin{array}{c}\text { Mother Inf } \\
\text { (5) }\end{array}$ & $\begin{array}{l}\text { Other Inf } \\
\text { (6) }\end{array}$ & $\begin{array}{l}\text { All } \\
(7)\end{array}$ & $\begin{array}{c}\text { Mother Inf } \\
\text { (8) }\end{array}$ & $\begin{array}{c}\text { Other Inf } \\
\text { (9) }\end{array}$ \\
\hline Treated Mother & $\begin{array}{c}0.020 \\
(0.009) \\
{[0.136]}\end{array}$ & $\begin{array}{c}0.020 * * \\
(0.006) \\
{[0.018]}\end{array}$ & $\begin{array}{c}0.020 \\
(0.025) \\
{[0.448]}\end{array}$ & $\begin{array}{c}0.028 * * * \\
(0.009) \\
{[0.008]}\end{array}$ & $\begin{array}{c}0.029 * * \\
(0.012) \\
{[0.018]}\end{array}$ & $\begin{array}{c}0.017 \\
(0.020) \\
{[0.554]}\end{array}$ & $\begin{array}{c}0.013 \\
(0.012) \\
{[0.295]}\end{array}$ & $\begin{array}{c}0.011 \\
(0.007) \\
{[0.194]}\end{array}$ & $\begin{array}{c}0.031 \\
(0.055) \\
{[0.676]}\end{array}$ \\
\hline Treated* Post Reform Mother & $\begin{array}{l}-0.023 \\
(0.015) \\
{[0.205]}\end{array}$ & $\begin{array}{l}-0.028 \\
(0.017) \\
{[0.184]}\end{array}$ & $\begin{array}{c}0.012 \\
(0.028) \\
{[0.680]}\end{array}$ & $\begin{array}{l}-0.034 * \\
(0.018) \\
{[0.081]}\end{array}$ & $\begin{array}{c}-0.047 * * \\
(0.018) \\
{[0.035]}\end{array}$ & $\begin{array}{c}0.034 \\
(0.037) \\
{[0.427]}\end{array}$ & $\begin{array}{l}-0.010 \\
(0.023) \\
{[0.673]}\end{array}$ & $\begin{array}{l}-0.007 \\
(0.029) \\
{[0.816]}\end{array}$ & $\begin{array}{l}-0.023 \\
(0.069) \\
{[0.752]}\end{array}$ \\
\hline Observations & 5,404 & 4,424 & 980 & 2,779 & 2,272 & 507 & 2,625 & 2,152 & 473 \\
\hline R-squared & 0.020 & 0.018 & 0.056 & 0.037 & 0.035 & 0.107 & 0.018 & 0.017 & 0.075 \\
\hline Calendar FE & YES & YES & YES & YES & YES & YES & YES & YES & YES \\
\hline Region FE & YES & YES & YES & YES & YES & YES & YES & YES & YES \\
\hline Cohort mother FE & YES & YES & YES & YES & YES & YES & YES & YES & YES \\
\hline Age controls & YES & YES & YES & YES & YES & YES & YES & YES & YES \\
\hline Mean pre-reform & 0.918 & 0.918 & 0.918 & 0.924 & 0.924 & 0.924 & 0.912 & 0.924 & 0.924 \\
\hline Std. dev. pre-reform & 0.274 & 0.274 & 0.274 & 0.264 & 0.264 & 0.264 & 0.283 & 0.264 & 0.264 \\
\hline
\end{tabular}

Note: The dependent variables in Panel A are the probability that a (1) mother of children older than 2 years old, (2) a mother with only boys, (3) a mother with only girls, (4) a mother with an only child that is a boy, or (5) a mother with only child that is a girl has private insurance. The dependent variables in Panel B are the probability of a (1-3) child, (4-6) boy or (7-9) girl has good subjective health, when this subjective health is self-reported by (2, $5,8)$ the mother or $(3,6,9)$ other informant. Regressions include cohort of the mother, and region dummies. We also include calendar time dummies, and children's age controls in Panel B. Treated are fathers born from January to May, and control are those born from August to December. Robust standard errors clustered at the mothers's cohort level in parentheses and the p-value of the wild bootstrap with 1000 replications in brackets. Source: (Panel A) European Community Household Panel (2000) and (Panel B) Spanish National Health Survey (2003, 2006, and 2011), all women with children from cohorts 1961-1971. Significance: $* * * \mathrm{p}<0.01, * * \mathrm{p}<0.05,{ }^{*} \mathrm{p}<0.1$. 


\section{Appendix}

Table A1: Descriptive Statistics of the Birth Statistics

\begin{tabular}{|c|c|c|c|c|c|c|c|c|c|c|c|c|c|c|c|c|c|c|c|c|}
\hline & \multicolumn{10}{|c|}{ Treated } & \multicolumn{10}{|c|}{ Not Treated } \\
\hline & \multicolumn{5}{|c|}{ Boys } & \multicolumn{5}{|c|}{ Girls } & \multicolumn{5}{|c|}{ Boys } & \multicolumn{5}{|c|}{ Gils } \\
\hline & Obs. & Mean & Std. Dev & Min. & Max. & Obs. & Mean & Std. Dev & Min. & Max. & Obs. & Mean & Std. Dev & Min. & Max. & Obs. & Mean & Std. Dev & Min. & Max. \\
\hline Maturity & 589777 & 90.63 & 29.14 & 0 & 100.00 & 551862 & 91.03 & 28.58 & 0 & 100 & 697905 & 90.74 & 28.98 & 0 & 100 & 653563 & 91.17 & 28.38 & 0 & 100 \\
\hline Multiple births & 589777 & 3.07 & 17.25 & 0 & 100 & 551862 & 3.19 & 17.57 & 0 & 100 & 697905 & 3.13 & 17.42 & 0 & 100 & 653563 & 3.29 & 17.83 & 0 & 100 \\
\hline Survive $24 \mathrm{~h}$ & 582965 & 99.78 & 4.71 & 0 & 100 & 545492 & 99.82 & 4.28 & 0 & 100 & 692566 & 99.78 & 4.64 & 0 & 100 & 648560 & 99.82 & 4.27 & 0 & 100 \\
\hline Birth Weight & 455977 & 3251.62 & 525.42 & 500 & 6400 & 428174 & 3135.51 & 496.07 & 500 & 6500 & 543688 & 3248.31 & 525.16 & 500 & 6400 & 510433 & 3133.20 & 494.63 & 500 & 6350 \\
\hline Weight less 2500 & 455977 & 6.66 & 24.94 & 0 & 100 & 428174 & 7.94 & 27.03 & 0 & 100 & 543688 & 6.78 & 25.14 & 0 & 100 & 510433 & 8.07 & 27.24 & 0 & 100 \\
\hline
\end{tabular}

Notes: Birth Statistics (1975-2014), all first births of Spanish women from cohorts 1961-1971 that had 14 to 43 years old at the moment of delivery. We drop first births of women born in 1966, that turned 14 the year the reform took place, and those of women born in July. Birth weight it is only available from the year 1980 onwards, so we restrict our sample for birth weight and the probability of having a child that weights less than 2500 grams to first birth of Spanish women from cohorts 1962-1971 that had 18 to 43 years old at the moment of delivery. 
Table A2: Descriptive Statistics of the Spanish National Health Surveys

\begin{tabular}{|c|c|c|c|c|c|c|c|c|c|c|c|c|c|c|c|c|c|c|c|c|}
\hline & \multicolumn{10}{|c|}{ Treated } & \multicolumn{10}{|c|}{ Not Treated } \\
\hline & \multicolumn{5}{|c|}{ Boys } & \multicolumn{5}{|c|}{ Girls } & \multicolumn{5}{|c|}{ Boys } & \multicolumn{5}{|c|}{ Gils } \\
\hline & Obs. & Mean & Std. Dev & Min. & Max. & Obs. & Mean & Std. Dev & Min. & Max. & Obs. & Mean & Std. Dev & Min. & Max. & Obs. & Mean & Std. Dev & Min. & Max. \\
\hline No Diabetes Asthma, Mental dis. or Allergies & 1534 & 0.80 & 0.40 & 0 & 1 & 1532 & 0.85 & 0.35 & 0 & 1 & 1537 & 0.80 & 0.40 & 0 & 1 & 1401 & 0.84 & 0.36 & 0 & 1 \\
\hline Fruit/Vegetables Everyday & 1531 & 0.70 & 0.46 & 0 & 1 & 1525 & 0.71 & 0.45 & 0 & 1 & 1530 & 0.69 & 0.46 & 0 & 1 & 1396 & 0.71 & 0.45 & 0 & 1 \\
\hline Proteins Everyday & 1528 & 0.21 & 0.41 & 0 & 1 & 1526 & 0.19 & 0.39 & 0 & 1 & 1529 & 0.19 & 0.39 & 0 & 1 & 1395 & 0.20 & 0.40 & 0 & 1 \\
\hline Cereals Everyday & 1530 & 0.93 & 0.25 & 0 & 1 & 1526 & 0.92 & 0.27 & 0 & 1 & 1529 & 0.93 & 0.26 & 0 & 1 & 1394 & 0.91 & 0.28 & 0 & 1 \\
\hline Bad Habits Everyday & 1537 & 0.01 & 0.08 & 0 & 1 & 1530 & 0.01 & 0.08 & 0 & 1 & 1538 & 0 & 0.07 & 0 & 1 & 1400 & 0.01 & 0.10 & 0 & 1 \\
\hline Hours Sleep & 1537 & 9.45 & 1.32 & 1 & 15 & 1532 & 9.40 & 1.33 & 2 & 19 & 1536 & 9.39 & 1.32 & 2 & 18 & 1402 & 9.52 & 1.30 & 1 & 16 \\
\hline Good Health & 1537 & 0.91 & 0.29 & 0 & 1 & 1533 & 0.91 & 0.28 & 0 & 1 & 1541 & 0.90 & 0.30 & 0 & 1 & 1403 & 0.90 & 0.30 & 0 & 1 \\
\hline
\end{tabular}

Notes: Spanish National Health Surveys (2003, 2006 and 2012), all children from ages 2 to 15 of Spanish women from cohorts 1961-1971. We drop children of women born in 1966, that turned 14 the year the reform took place, and those of women born in July.

Table A3: Descriptive Statistics of the European Community Household Panel

\begin{tabular}{|c|c|c|c|c|c|c|c|c|c|c|c|c|c|c|c|c|c|c|c|c|}
\hline & \multicolumn{10}{|c|}{ Treated } & \multicolumn{10}{|c|}{ Not Treated } \\
\hline & \multicolumn{5}{|c|}{ All Boys } & \multicolumn{5}{|c|}{ All Girls } & \multicolumn{5}{|c|}{ All Boys } & \multicolumn{5}{|c|}{ All Girls } \\
\hline & Obs. & Mean & Std. Dev & Min. & Max. & Obs. & Mean & Std. Dev & Min. & Max. & Obs. & Mean & Std. Dev & Min. & Max. & Obs. & Mean & Std. Dev & Min. & Max. \\
\hline \multirow[t]{3}{*}{ Private Insurance } & 228 & 0.11 & 0.32 & 0 & 1 & 239 & 0.15 & 0.35 & 0 & 1 & 269 & 0.11 & 0.32 & 0 & 1 & 262 & 0.12 & 0.33 & 0 & 1 \\
\hline & \multicolumn{5}{|c|}{ Only Child Boy } & \multicolumn{5}{|c|}{ Only Child Girl } & \multicolumn{5}{|c|}{ Only Child Boy } & \multicolumn{5}{|c|}{ Only Child Girl } \\
\hline & Obs. & Mean & Std. Dev & Min. & Max. & Obs. & Mean & Std. Dev & Min. & Max. & Obs. & Mean & Std. Dev & Min. & Max. & Obs. & Mean & Std. Dev & Min. & Max. \\
\hline Private Insurance & 146 & 0.10 & 0.30 & 0 & 1 & 135 & 0.19 & 0.40 & 0 & 1 & 153 & 0.10 & 0.31 & 0 & 1 & 180 & 0.14 & 0.35 & 0 & 1 \\
\hline
\end{tabular}

Notes: European Community Household Panel (2000), all children from ages 2 to 15 of Spanish women from cohorts 1961-1971. We drop children of women born in 1966, that turned 14 the year the reform took place, and those of women born in July. 
Table A4: Medium-run effect of the reform on children's objective health, for both parents

\begin{tabular}{|c|c|c|c|c|c|c|c|c|c|}
\hline & \multicolumn{3}{|c|}{$\begin{array}{l}\text { No Diabetes, Asthma } \\
\text { Mental dis. or Allergies }\end{array}$} & \multicolumn{3}{|c|}{$\begin{array}{c}\text { Fruit/Vegetables } \\
\text { everyday }\end{array}$} & \multicolumn{3}{|c|}{$\begin{array}{l}\text { Proteins } \\
\text { everyday }\end{array}$} \\
\hline & $\begin{array}{l}\text { All } \\
(1)\end{array}$ & $\begin{array}{l}\text { Boys } \\
(2)\end{array}$ & $\begin{array}{l}\text { Girls } \\
(3)\end{array}$ & $\begin{array}{l}\text { All } \\
(4)\end{array}$ & $\begin{array}{c}\text { Boys } \\
(5)\end{array}$ & $\begin{array}{l}\text { Girls } \\
(6)\end{array}$ & $\begin{array}{l}\text { All } \\
(7)\end{array}$ & $\begin{array}{c}\text { Boys } \\
(8)\end{array}$ & $\begin{array}{l}\text { Girls } \\
(9)\end{array}$ \\
\hline \multirow[t]{3}{*}{ Both Treated } & 0.005 & -0.011 & 0.021 & 0.009 & 0.046 & -0.033 & -0.024 & -0.029 & -0.011 \\
\hline & $(0.016)$ & $(0.026)$ & $(0.029)$ & $(0.026)$ & $(0.058)$ & $(0.024)$ & $(0.025)$ & $(0.024)$ & $(0.031)$ \\
\hline & {$[0.821]$} & {$[0.661]$} & {$[0.463]$} & {$[0.733]$} & {$[0.460]$} & {$[0.187]$} & {$[0.410]$} & {$[0.287]$} & {$[0.760]$} \\
\hline \multirow[t]{3}{*}{ Both Post Reform } & 0.022 & $0.084 *$ & -0.016 & 0.030 & -0.002 & $0.068^{*}$ & 0.008 & 0.013 & -0.003 \\
\hline & $(0.046)$ & $(0.036)$ & $(0.046)$ & $(0.034)$ & $(0.051)$ & $(0.030)$ & $(0.030)$ & $(0.074)$ & $(0.052)$ \\
\hline & {$[0.708]$} & {$[0.099]$} & {$[0.727]$} & {$[0.488]$} & {$[0.950]$} & {$[0.067]$} & [0.797] & {$[0.867]$} & {$[0.959]$} \\
\hline \multirow[t]{3}{*}{ Both Treated* Post Reform } & 0.036 & $0.064 *$ & 0.007 & -0.012 & 0.034 & -0.043 & 0.043 & 0.076 & 0.010 \\
\hline & $(0.027)$ & $(0.031)$ & $(0.052)$ & $(0.030)$ & $(0.074)$ & $(0.050)$ & $(0.040)$ & $(0.044)$ & $(0.041)$ \\
\hline & {$[0.239]$} & {$[0.057]$} & {$[0.888]$} & {$[0.716]$} & {$[0.646]$} & {$[0.395]$} & {$[0.360]$} & {$[0.112]$} & {$[0.809]$} \\
\hline Observations & 2,479 & 1,279 & 1,200 & 2,478 & 1,279 & 1,199 & 2,478 & 1,279 & 1,199 \\
\hline R-squared & 0.048 & 0.060 & 0.064 & 0.040 & 0.063 & 0.050 & 0.169 & 0.166 & 0.203 \\
\hline Calendar FE & YES & YES & YES & YES & YES & YES & YES & YES & YES \\
\hline Region FE & YES & YES & YES & YES & YES & YES & YES & YES & YES \\
\hline Cohort mother FE & YES & YES & YES & YES & YES & YES & YES & YES & YES \\
\hline Age controls & YES & YES & YES & YES & YES & YES & YES & YES & YES \\
\hline Mean pre-reform & 0.827 & 0.793 & 0.865 & 0.697 & 0.694 & 0.700 & 0.213 & 0.208 & 0.218 \\
\hline \multirow[t]{3}{*}{ Std. dev. pre-reform } & 0.378 & 0.405 & 0.342 & 0.460 & 0.461 & 0.458 & 0.409 & 0.406 & 0.413 \\
\hline & \multicolumn{3}{|c|}{ Cereals everyday } & \multicolumn{3}{|c|}{ Bad habits everyday } & \multicolumn{3}{|c|}{ Hours sleep } \\
\hline & $\begin{array}{l}\text { All } \\
(7)\end{array}$ & $\begin{array}{c}\text { Boys } \\
(8)\end{array}$ & $\begin{array}{l}\text { Girls } \\
(9)\end{array}$ & $\begin{array}{c}\text { All } \\
(10) \\
\end{array}$ & $\begin{array}{l}\text { Boys } \\
(11)\end{array}$ & $\begin{array}{l}\text { Girls } \\
(12)\end{array}$ & $\begin{array}{l}\text { All } \\
(13) \\
\end{array}$ & $\begin{array}{l}\text { Boys } \\
(14)\end{array}$ & $\begin{array}{l}\text { Girls } \\
(15)\end{array}$ \\
\hline \multirow[t]{3}{*}{ Both Treated } & -0.013 & -0.002 & -0.020 & 0.001 & 0.004 & -0.003 & -0.022 & 0.067 & $-0.144 * *$ \\
\hline & $(0.019)$ & $(0.027)$ & $(0.020)$ & $(0.008)$ & $(0.010)$ & $(0.006)$ & $(0.052)$ & $(0.069)$ & $(0.067)$ \\
\hline & {$[0.711]$} & {$[0.941]$} & {$[0.410]$} & {$[0.922]$} & {$[0.891]$} & {$[0.661]$} & {$[0.665]$} & {$[0.339]$} & {$[0.047]$} \\
\hline \multirow[t]{3}{*}{ Both Post Reform } & 0.017 & 0.038 & -0.003 & 0.002 & 0.002 & 0.009 & -0.114 & 0.071 & -0.232 \\
\hline & $(0.022)$ & $(0.038)$ & $(0.036)$ & $(0.009)$ & $(0.012)$ & $(0.010)$ & $(0.193)$ & $(0.271)$ & $(0.237)$ \\
\hline & {$[0.427]$} & {$[0.351]$} & {$[0.928]$} & {$[0.818]$} & {$[0.881]$} & {$[0.427]$} & [0.583] & {$[0.796]$} & {$[0.372]$} \\
\hline \multirow[t]{3}{*}{ Both Treated* Post Reform } & $0.067 * *$ & $0.067 *$ & $0.062 *$ & -0.006 & -0.008 & -0.004 & 0.053 & 0.116 & 0.007 \\
\hline & $(0.024)$ & $(0.033)$ & $(0.027)$ & $(0.008)$ & $(0.010)$ & $(0.008)$ & $(0.116)$ & $(0.193)$ & $(0.159)$ \\
\hline & {$[0.017]$} & {$[0.066]$} & {$[0.074]$} & {$[0.601]$} & {$[0.529]$} & [0.619] & {$[0.665]$} & {$[0.599]$} & {$[0.969]$} \\
\hline Observations & 2,478 & 1,279 & 1,199 & 2,479 & 1,279 & 1,200 & 2,479 & 1,279 & 1,200 \\
\hline R-squared & 0.066 & 0.072 & 0.089 & 0.018 & 0.030 & 0.032 & 0.254 & 0.270 & 0.261 \\
\hline Calendar FE & YES & YES & YES & YES & YES & YES & YES & YES & YES \\
\hline Region FE & YES & YES & YES & YES & YES & YES & YES & YES & YES \\
\hline Cohort mother FE & YES & YES & YES & YES & YES & YES & YES & YES & YES \\
\hline Age controls & YES & YES & YES & YES & YES & YES & YES & YES & YES \\
\hline Mean pre-reform & 0.920 & 0.932 & 0.907 & 0.00684 & 0.00657 & 0.00713 & 9.402 & 9.405 & 9.399 \\
\hline Std. dev. pre-reform & 0.271 & 0.252 & 0.290 & 0.0824 & 0.0808 & 0.0842 & 1.237 & 1.255 & 1.219 \\
\hline
\end{tabular}

Notes: The dependent variables are the probability that a child, boy or girl $(1,2,3)$ has no diabetes, asthma, mental disorders or chronic allergies , $(4,5,6)$ eats fruits and vegetables, $(7,8,9)$ eats proteins (meat, fish or eggs), $(10,11$, 12) eats cereals (bread or pasta), $(13,14,15)$ has bad habits (eats cold meat or has nothing for breakfast) everyday, and $(16,17,18)$ children's hours of sleep a day. Regressions include cohort of the mother, father, calendar time, and region dummies. We also include children's age controls. Both Treated are parents both born from January to May, and Both Control are those born from August to December. Robust standard errors clustered at the mothers's cohort level in parentheses and the p-value of the wild bootstrap with 1000 replications in brackets. Source: Spanish National Health Survey (2003 and 2011), all parents with children from cohorts 1961-1971. Significance: $* * * \mathrm{p}<0.01, * * \mathrm{p}<0.05, * \mathrm{p}<0.1$. 
Table A5: Effect of the father's reform on infant health outcomes at delivery by gender

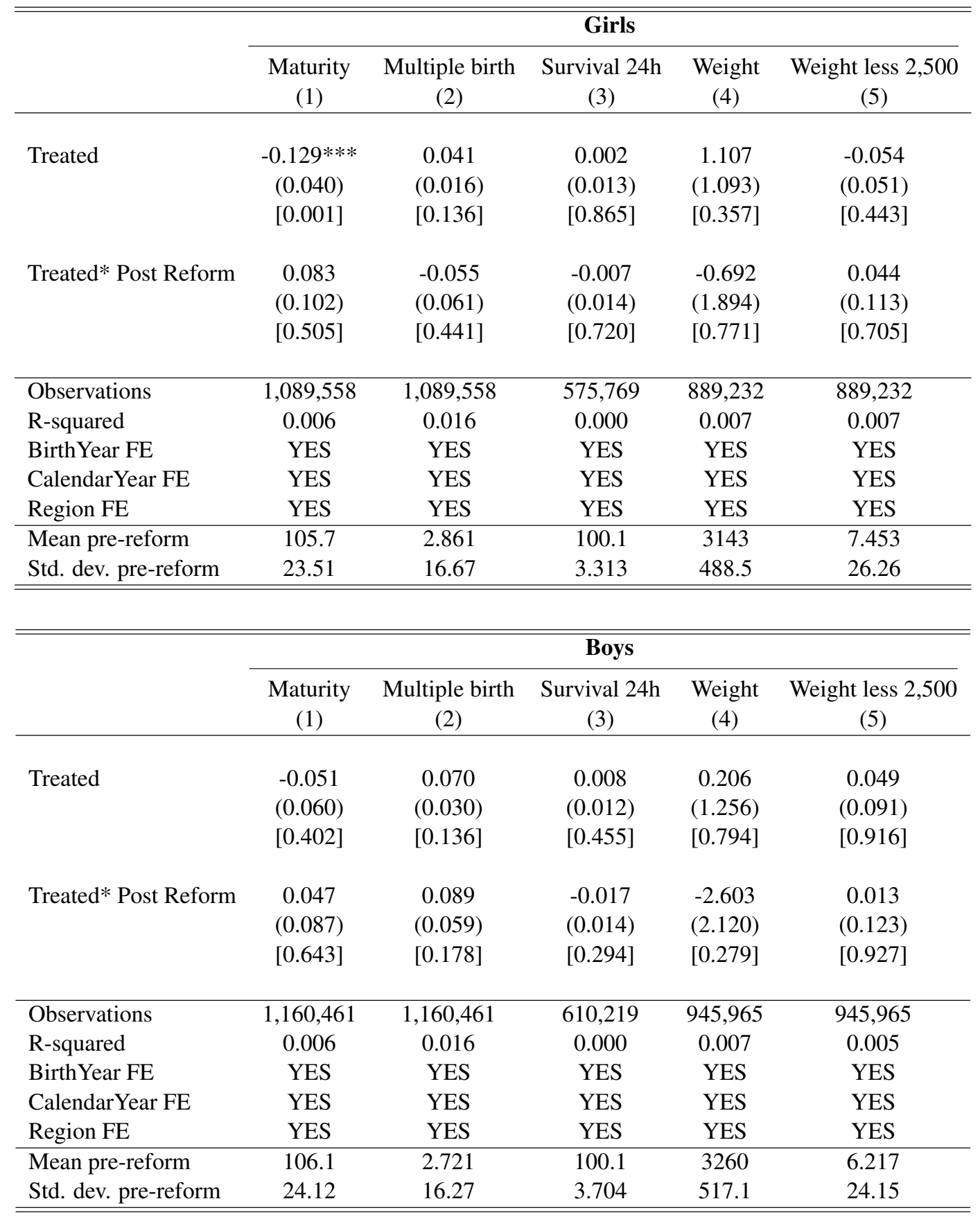

Notes: The dependent variables are (1) the probability of having a first child with less than 37 weeks of gestation, (2) the probability of having multiple births, (3) the probability of having a first child that survives the first 24 hours after delivery, (4) the weight at birth of the woman's first child and, (5) the probability that the first child is born with less than 2,500 grams. Regressions include father's cohort, calendar time and region dummies. Treated fathers are individuals born from January to May, and control fathers are those born from July to December. Robust standard errors clustered at cohort level in parentheses and the p-value of the wild bootstrap with 1000 replications in brackets. Source: Birth registries (1975-2014), all men from cohorts 1961-1971. For birth-weight, only consider the birth registries from 1980-2014 and cohorts of men 1962-1971. Significance: $* * * \mathrm{p}<0.01, * * \mathrm{p}<0.05,{ }^{*} \mathrm{p}<0.1$. 